\title{
From Mounds to Monasteries: A Look at Spiro and Other Centers Through The Use of Metaphor
}

Robert L. Brooks

Oklahoma Archeological Survey

Follow this and additional works at: https://scholarworks.sfasu.edu/ita

Part of the American Material Culture Commons, Archaeological Anthropology Commons, Environmental Studies Commons, Other American Studies Commons, Other Arts and Humanities Commons, Other History of Art, Architecture, and Archaeology Commons, and the United States History Commons

Tell us how this article helped you.

This Article is brought to you for free and open access by the Center for Regional Heritage Research at SFA ScholarWorks. It has been accepted for inclusion in Index of Texas Archaeology: Open Access Gray Literature from the Lone Star State by an authorized editor of SFA ScholarWorks. For more information, please contact cdsscholarworks@sfasu.edu. 
From Mounds to Monasteries: A Look at Spiro and Other Centers Through The Use of Metaphor

\section{Creative Commons License}

(c) (1) (9)

This work is licensed under a Creative Commons Attribution-NonCommercial 4.0 International License 


\title{
From Mounds to Monasteries: \\ A Look at Spiro and Other Centers Through The Use of Metaphor
}

\author{
Robert L. Brooks \\ Oklahoma Archeological Survey
}

\begin{abstract}
Previous study of the extensive and elaborate funerary offerings at the Spiro site have explained their presence by an exchange system with Spiro functioning as a gateway center. More recently, Schambach has argued extensively and passionately for Spiro's role as an entrepôt redistributive center. However, this argument fails to account for much of the accumulation of funerary items present at Spiro. As an alternative, I propose that some ceremonial centers such as Spiro functioned solely as religious centers, much like the monasteries of medieval Europe with parallels in the use of architecture, economic support, relics, and the treatment of individuals at death. A model based on the metaphor of monastic life provides greater explanatory potential than that of the economically-driven entepôt.
\end{abstract}

\section{INTRODUCTION}

The Spiro (Le Flore County), Harlan (Cherokee County), and Norman (Wagoner County) sites residing in the Arkansas River valley system of eastern Oklahoma represent some of the most western of the complex ceremonial centers of the Mississippian world. The three Oklahoma centers contain conjoined burial mounds, temple mounds, as well as numerous smaller charnel house mounds. All offer elaborate evidence of Mississippian mortuary and funerary practices within the context of an Arkansas River Caddoan society. Because of the extensive and exotic funerary inventory and the spectacular mortuary events at Spiro, as well as the occurrence of archeological investigations in the mid- to late 1930s, this center has received the bulk of the attention by archaeologists. Harlan (Bell 1972) and Norman (Finkelstein 1940), however, may be equally deserving. The architecture of Spiro as a ceremonial center, and the richness of the material record, were documented early on by Bell (1947), Orr (1952), and Hamilton (1952).

Later work by Brown (1966a, 1966b, 1971, 1975) examined the complex developmental history of Spiro (including comprehensive description of the material culture), whereas other studies focused on stylistic aspects of the engraved shell (Duffield 1964), and societal complexity (Rogers 1983, 1996). The exotic and non-local origin for many of the funerary offerings at Spiro and their ties to the Southeastern Ceremonial Complex prompted extensive discussion of trade networks (cf., Bell 1947; Brown 1966a, 1966b, 1983; Wyckoff 2001). More recently Brown (1996) addressed the issue of trade in his two volumes on Spiro, while numerous researchers have worked to refine the origin of non-local materials from Spiro (e.g., Brown and Rogers 1989). 
Frank Schambach (1993a, 1993b, 1994, 1999, 2000) has argued extensively and passionately for Spiro serving as a redistributive trade center. Schambach proposed that Spiro, occupied by ancestral Tunica, functioned as an entrepôt with Spiroan traders redistributing goods from the Plains (e.g., bison meat and hides) in exchange for Osage orange wood and goods with ceremonial histories from the Southeast and Midwest. In this fashion, Spiro would have functioned as a gateway community between the Mississippian world and that of the Plains societies to the west (cf. Hirth 1978). He further argues for outposts of the Spiro entrepôt at the Sanders site in northeastern Texas and the Nagle site in central Oklahoma (Schambach 1999, 2000; see Bruseth, Wilson, and Perttula [1995] and Brooks [1996] for a response to this argument).

Redistributive economies figured prominently in the early discussions of chiefdom-level society (Sahlins 1972) and have been applied to Mississippian society, including centers such as Cahokia, Moundville, and Spiro. Subsequent critical reexamination by Earle (1997) and Peebles and Kus (1977) documented considerable variation in how redistribution was applied by chiefdom-level societies, and in some instances, there was little evidence for a redistributive system present. However, the use of trade and redistributive models continues to be applied to Mississippian societies using multiple and/or alternative models (e.g., Welch 1991; Peregrine 1992). The application and study of redistributive potential within Mississippian chiefdom societies undoubtedly has merit for the understanding of the complex relationships that existed on the cultural landscape, within communities and societies where class inequality was present, and even between ceremonial centers of differing prestige and power. There is not a consensus, though, as to the role of trade and redistribution. Others, notably Pauketat (1997) and Emerson (2004), argue that too much reliance has been placed on trade and redistribution as an explanation for the dynamics of interaction between (for example) Cahokia and the regions and ethnicities that comprise the Mississippian world.

\section{THE ENTREPOT AS METAPHOR}

While Schambach's suggestion of a Tunican presence at Spiro and its outposts is provocative, arguing for ethnicity in a prehistoric context remains an elusive undertaking. Schambach (1999) has a valid argument in that the annular fronto-vertico-occipatal cranial deformation practiced by Arkansas River valley (and Sanders in Texas) elites is significantly different from the tabular frontal-occipital style in the Caddoan region. This is best expressed in the distinction between elites at the Sanders site and those at surrounding Caddoan centers (Derrick and Wilson 1997). However, it is unclear whether this reflects a stylistic difference related to participation in the Mississippian World or to an ethnic/cultural or even biological population difference. There are means at our disposal to critically examine this hypothesis, however, such as refined craniometrics (Owsley and Jantz 1999) as well as the examination of comparative DNA sampling. Opportunities to resolve this critical issue must await future collaboration with the concerned tribes (e.g., the Wichita, the Caddo, and the Tunica). It should also be pointed out that the "Big Bang" theory of Cahokian expansion proposed movement of Middle Mississippian populations from Cahokia to the north, Midwest, and Southeast (cf. Pauketat 2005) and thus, immigrant populations are a possibility throughout much of the Mississippian world. However, attention here is turned to the portion of the entrepôt model that deals with the redistribution of goods. There are two goals in examining the entrepôt model. The first is to look at the theoretical implications of this system: how does it function and what are the outcomes? The second goal is to examine what can be documented as the products of the proposed entrepôt system in the context of redistribution at Spiro and other Arkansas River valley Caddoan centers.

In examining the entrepôt model, one of the initial steps is to define what is meant by the term. Entrepôt is defined by Webster's (1979:608) as "a warehouse or place for the storage of goods or (2) the distributing point 
for goods." Goods in the entrepôt system would be warehoused at a given location or depot. From here, the goods would flow to external distribution or redistribution points. In this system, there are also examples where there is a backflow from these other point to the warehouse and back-up the linkage to the origin point. The warehouse or entrepôt would be administered by elites, nobles, or merchants who dealt with their trading partners in the external group. In some ways the entrepôt model corresponds to a world systems approach (cf. Wallerstein 1979) where a developed economic system interacts with less complex societies. Here, the relationship between the entrepôt and the exogenous culture would be hierarchical. It is unclear whether interaction between Spiroan society and the less complex Plains groups would have functioned in this fashion.

From this perspective, it is appropriate to examine the storage and/or distribution aspect of the Sanders and Nagle sites. The Nagle site, located in northeast Oklahoma County, Oklahoma, was initially identified as a cemetery location for Spiro phase people (Brues 1957). No village site has been documented, however, and thus, there is no location from which to examine the issue of warehousing or redistribution of goods. While Schambach proposes this as an entrepôt location, there is no evidence to support this assertion. There are individuals within a cemetery context exhibiting attributes of a Spiroan population (Owsley 1989), but there is no support for a residential population.

Examining the issue of redistribution of Spiroan/Mississippian goods within the broader perspective, there is insufficient evidence to point to some site functioning as a redistributive center for the Southern Plains area. There are some Spiro phase items that occur at Plains Village settlements in south-central and west-central Oklahoma (Carney 1993). In some cases though, such as the Zwiginclose site in Pawnee County, it is unclear whether we are dealing with another Spiroan "outpost" or Spiroan goods at a Plains Village settlement. Typically, these goods have been ear spools or ceramics. There are none of the more exotic materials common to Spiro. The engraved shell gorget initially attributed to a Washita River phase site near Chickasha (Drass and Peterson 1985) was later rumored to have been found at Lake Eufaula, perhaps from the inundated Eufaula Mound. There is only one platform pipe for all of western Oklahoma and this item lacks similarity to the Spiroan T-shaped pipes as well as a context to demonstrate it functioned as a prestige good. Additionally, petrographic analysis of Caddoan style ceramics on the Southern Plains has revealed many of them to be replicas (Ferring and Perttula 1987). If goods are being redistributed through Nagle or some other Spiroan outpost on the Plains of Oklahoma, they were remarkably poor "traders." The backflow of Plains goods to Spiro or other center is equally sparse. There are high quality chipped stone blades of Florence A chert at Spiro. But, these could have been acquired by any number of means, including direct procurement by Spiroan traveling up the Arkansas River to the source. Bison meat and hides have been proposed by Schambach as a likely material to have been exchanged with Arkansas River Caddoan populations, but as noted by Brown (1996), aside from the use of some bison hair in weaving and a few etchings on the engraved shell, there is not a bison presence at Spiro or at other Arkansas River ceremonial centers. Bison remains are found in relative abundance at Fort Coffee phase villages around Spiro, but their appearance in these villages does not take place until after the demise of Spiro and the other mound centers in the Arkansas River valley. It is also likely that these bison were a consequence of direct procurement by Fort Coffee phase populations rather than through trade/exchange. This point was stressed in an earlier article treating the role of bison in such an exchange system (Brooks 1996). There is an equal absence of data to support a hide production "economy" for Plains Village settlements contemporaneous with Spiro. In fact, there has been no argument from archeologists studying southern Plains Village sites in recent years for the presence of such trade in bison hides or meat. Such evidence is available for the ensuing Protohistoric period (ca., A.D. 1450-1600), when extensive trading takes place between people on the Plains and southwestern Puebloan societies (Spielman 1991). If such trade in bison hides and meat was also moving to the east in Protohistoric times, it would have been without the presence of the gateway of Spiro. 
Two cases of long distance movement of goods to Spiro also merit attention, especially as they have not been previously discussed in the context of the entrepôt metaphor. There is evidence for Olivella dama shell originating from the Gulf of California present at Spiro in substantial quantities (Kozuch 2002). But it is unclear as to how these items are being delivered. Are they delivered as a consequence of a Southwest Pueblos-Plains-Arkansas River valley interaction or is it more of a direct connection to the California coast area? Kozuch is skeptical that Spiroans would have had sufficient knowledge of the California landscape to locate areas where the Olivella dama shell could be found. It is perhaps significant that $93 \%$ of the Olivella shell at Spiro is found with Burial 145. If Olivella shell represents a redistributed item within an entrepôt system, presumably, it would be more widely represented among the elites at Spiro. There is one remaining item from Spiro that merits some discussion. This is the single piece of obsidian (a scraper) found at the site and that has been sourced to near Pachuca, Mexico (Barker et al. 2002). This represents the only item of Mesoamerican origin from all of the southeastern ceremonial centers and cannot at this time be articulated to a Mesoamerican entepôt moving goods to Spiro.

At the Sanders site in Lamar County, Texas (Krieger 1946; Jackson et al. 2000), a different situation exists. Unquestionably, a resident population is present that differs significantly from neighboring villagers. But, can it be clearly established that this resident population was involved in a redistributive network? There were 21 conch shell dippers, gorgets, and pendants as well as 5500 beads from conch shell found within burial contexts at Sanders. These items were also noted as stylistically resembling those found at Spiro (Krieger 1946:177). However, there is a question as to the origin of the engraved shell at Spiro (Brown 1996) and a similar issue exists for the Sanders shell as well. There is no way to establish that it originated at Spiro. Without evidence to support these goods coming from Spiro, the entrepôt argument lacks substance. The other issue, of course, is that these and other items were not maintained in the system but were deposited as mortuary furniture.

Additionally, 18 bison scapula hoes were found within burial contexts at Sanders (Krieger 1946:183). There appears to be some confusion, however, as to the context of some of these specimens (Bruseth et al.1995). There are numerous references as to the long distance hunts of the Caddo for bison in historic times. Joutel also noted that bison scapula were used as mattocks by the Caddo of Louisiana (in Swanton 1942:127). Are the Sanders burials with scapula hoes, prehistoric or historic? Assuming that these hoes are indeed part of the mortuary furniture for the prehistoric Sanders' elites, there remains a significant problem. If the purpose of the Sanders site entrepôt is to redistribute Plains goods, why were these scapula hoes placed in burial contexts rather than being directed back up the line to Spiro? Considering the scarcity of such items at Spiro, they should have been highly prestigious and merited backflow to the principal center in the system. Yet, there are no data to support such a redistributive system for the bison tools.

Similar questions arise for Spiro and its role as the central "entrepôt." Spiro is a center where ceremonial goods or relics are found within the archeological context as funerary offerings. Thus, most goods are not redistributed elsewhere but are deposited as the funerary offerings with or for high status individuals within the mortuary system. From this perspective, Spiro does not function to redistribute prestige items/goods. A similar argument has been made for Cahokia by Pauketat (1997). He argues that many of the goods at Cahokia are not from a Mississippian World redistributive system but originated in close proximity to Cahokia (within $150 \mathrm{~km}$ ). From Cahokia, they subsequently were redistributed but possibly not as part of some system that precipitated a reciprocity in goods coming back to the originating center. This perspective does not discount redistribution functioning in Cahokian society, the Mississippian World, or at Spiro in a more general sense, but perhaps without villages or settlements solely established to regulate the flow of such goods, or that the redistribution, as such, played a prominent role in the function of mortuary/religious practices at the ceremonial centers. The goods may have been valued for the prestige or value they were embodied with and the nature of their acquisition was of secondary importance. 


\section{THE MONASTERY AS METAPHOR}

While questions have been raised on the use of the entrepôt as a metaphor to explain the presence of prestige goods in a funerary context and associated aspects of ceremonial centers and their practices, is there a more plausible alternative explanation, through use of metaphor or otherwise? Emerson and Hughes' (2000) study of flint clay figurines and pipes originating from Cahokia provide an intriguing base from which to begin this examination. Numerous large stone figurines and pipes have been described from mortuary contexts at Spiro. Study of these specimens as well as others by Emerson and Hughes using x-ray diffraction identified them as being made of flint clay originating in the Ozarks area adjacent to Cahokia. They further argue that these pipes with Cahokian stylistic features were resident at Cahokia and later transported to Spiro, possibly after their use-life had ended for Cahokia priestly elites. More recent analysis of flint clay objects at the Gahagan site in Louisiana attest to delivery of the figurines from Cahokia somewhere between A.D. 1021 and 1160 (Emerson and Girard 2004). In earlier studies, Phillips and Brown (1984:170-174) established a relationship between engraved conch shell of the Braden style at Spiro to similar stylistic elements at Cahokia. Thus, we have two fundamentally different materials, flint clay and Florida Keys/Gulf Coast shell being linked at Spiro to Cahokia, with the figurines originating from Cahokia. There are numerous other exotic goods in a mortuary context at Spiro that are from analogous long-distance origins (e.g., copper, stone, mica, and the previously discussed Olivella shell and obsidian). As noted above, these items are not redistributed; they enter the mortuary/ceremonial context with little evidence to suggest existence as a functional item in society. What kind of system can account for this type of distribution? An economic redistributive system has not provided a satisfactory explanation.

While any number of world examples could potentially be applied for its parallels or metaphorical comparisons, it is argued here that the example of monasteries in medieval European societies functions as a metaphor that better accounts for much of the behavior witnessed in the ceremonial/symbolic life of the Mississippian world, including Cahokia and the movement of material to Spiro. There are obviously, significant differences between life in medieval Europe and that of contemporaneous village farming societies in the Midwestern and Southeastern United States. It would be presumptuous to argue that the priestly elites of the Mississippian world and the elites of the intermeshed secular and sacred political states of Europe are equivalent. Yet, there are intriguing parallels if we isolate the monastic patterns of the Catholic Church during this time and deconstruct their economic, social, and religious ways-of-life and also examine basic patterns in architecture.

The Catholic Church during medieval times was highly embedded within the feudal states of Europe. Secular rulers of these feudal states sought to sanctify their position through the church. Religious practices of the church functioned at various levels within society. There were highly ranked church officials seated at basilicas in cities such as Paris, Rome, Madrid, Munich, etc. While lacking the prominence of the basilicas and major cathedrals, there were lesser cathedrals in secondary cities throughout western Europe, usually administered by a bishop. Most towns also had their local church and priest. Functioning outside this hierarchy was the monastery. Monasteries, while sponsored by the leaders of feudal states, typically functioned apart from urban centers and their church structures, and were more focused on religious teachings and philosophy than their counterparts in the towns and cities. 


\section{HISTORY OF MONASTIC LIFE}

Monastic life was an attempt on the part of monks to come closer to God. This tradition began during the fourth century in Egypt as monks traveled into the desert in their search for a greater sense of worthiness (Brooke 2003). In ca. A.D. 530 Saint Benedict wrote the rules of monastic life. This marked the beginning of the movement of monks to monasteries in search of enlightenment. Monasteries continued to increase in numbers and power until the eighth to ninth centuries when their numbers decreased as a result of an increase in secular society. However, monasticism returned to favor in the tenth century with establishment of the monastery at Cluny and the beginning of the "Cluniac" order (Lawrence 1984). By the twelfth century there were 75 houses under the House of Cluny and following the principles of the Cluniac order in France. Others, advocates of the House of Gorze, were present in Germany. In the thirteenth century, an order that thought the Benedictines and Cluniacs had not disavowed themselves thoroughly enough of wealth was established, the Cistercians. The Cistercians were the most rigid of the monastic orders in their vows of poverty and in their efforts to come closer to God through sacrifices on earth. These various orders spread throughout Europe during the Middle Ages, extending into Great Britain and northern Europe. The presence of monks and monasteries continue in most European countries today, although without the power and prestige that they held some 1000 years in the past.

\section{PARALLELS OF MONASTIC LIFE AND THE MISSISSIPPIAN WORLD}

A fundamental aspect of monastic life was that of privilege. The nobility was responsible for the founding of monasteries and its members were their inhabitants (Milis 1992:44). This is further accentuated by the presence of a hierarchical structure among most monastic orders that only persons of noble birth could be monks or have priestly functions. The illiterate or commoners became the "conversi" or lay brothers who performed domestic functions for the noble/ascribed status monks (Milis 1992:18). Within the order of monks, there was a rigid hierarchy with the abbot as the principal for a particular house or series of houses. This is not unlike what we think to be the situation at the Arkansas River valley centers and in the Mississippian World where priests represent the nobles or elites of society. The structure of the Mississippian World also suggests that there existed a structure in the hierarchy of priests and individuals associated with priestly functions. Within the context of Mississippian ceremonial centers (places such as Spiro), undoubtedly, there were also the equivalents of "conversi" who performed domestic tasks for the priestly elites as attendants.

There was a formalized daily ritual of activities within the monastery. Most of these dealt with prayer or work activities (tied to sacred functions rather than secular ones). This daily liturgy served as the basic scheduling for monastic life and religious behavior. Obviously, such details of daily activity cannot be extracted at prehistoric sites. However, it is logical that the priestly elites residing at Spiro, Cahokia, and other centers would perform the equivalent of the daily liturgy. While some religious functions operated on a calendar schedule undetectable by archeologists, other activities, undoubtedly, required daily attention. Associated with daily religious activities is the use of incense for highly ritualized purification ceremonies. Similar actions are documented for Southeastern societies except that the medium used in such ceremonies was tobacco (Swanton 1942).

Another parallel lies in the composition of residents at ceremonial centers and monasteries. The residents at monasteries were the monks, the conversi who functioned as their attendants or who provided basic support tasks, and a few other lay individuals who provided logistical support for the existence of the monastery. There were few if any individuals not associated with the function of the monastery in residence (Lawrence 2001). 
This pattern is very similar to that found at a number of Mississippian ceremonial centers where there was not a resident domestic population. This is certainly true at Spiro and other Arkansas River valley centers where there were no residents other than the priestly elites (and their presumed attendants). This suggests that there is a sacred nature to the space of the ceremonial center and the monastery that cannot be supplanted by domestic concerns. In the case of the monastery, there is sacredness to the physical space of the monastery such that village populations were not encouraged to take up residence. Perhaps a similar atmosphere prevailed in the Mississippian World.

A corollary to this also existed in the role of the local village. In medieval Europe, the village residents performed many domestic tasks for the monastery. They provided the food for the occupants as well as other goods such as clothing, tools, furniture, and masonry. Thus, the monastery was dependent on the local village community for much of their needs. A similar scene is replayed in the surroundings of Spiro and other centers. The nearby village residents provided most of their needs. Obviously, Spiro elites would not be contributing to production of food and other goods as the priestly elites of Caddoan society. However, it is somewhat less clear whether the nearby villages were also the suppliers for many of the non-food items that we find in a mortuary context at Spiro and other centers.

Residents of surrounding villages also routinely visited the monastery during times of feasts and rituals. There are numerous accounts of an inflow of local "lay" people that experienced and/or were participants in feasts and celebrations at local monasteries (Brooke 2003). It is likely that at least some of these celebrations dealt with the death of significant members of the religious community. These contexts would not be unlike those experienced by the Mississippian community that visited the ceremonial center at specific times and would also take place upon the death of individuals within the priestly elites of Mississippian society. There would be little to document the presence of the "lay" people at these events except for the occasional need for their labor or as in the case of Cahokia, as sacrifices.

A major function of the Mississippian ceremonial center was to serve as a repository for deceased priestly elites within the society. Typically, they were interred in burial mounds after residing for some time in charnel houses. Both types of structures were present at the ceremonial centers. It might be assumed that this is significantly different from the practices of monasteries in medieval Europe, yet that is not the case. Many of the monks, abbots, and other religious functionaries of monastic life died at the monastery and were buried within the facilities. Often, the tombs were dug as deep chambers within structures of the monastery and are recognized as the catacombs (Brooke 2003). These burial plots became points of worship for subsequent generations of monks and lay visitors. Even the bone pickers of the historic Caddo society documented as cleaning priestly elites remains have their counterparts in medieval Europe. There are also bone pickers in Europe at this time. What is less clear is the remains that they were treating. However, it is assumed that the Caddo bone pickers would be most concerned with the remains of the nobles and elite, especially the religious elite. This practice may also have a corollary in the contemporaneous societies of medieval Europe.

There are also a series of parallels in treatment of the dead and the holdings of sacred items between monasteries and ceremonial centers such as Spiro. Abbots and monks who died while in residence were sometimes buried with sacred items associated with their lives. Today, one can visit monasteries across Europe and see the burial vaults of these prior monastic residents. There was also considerable ceremony associated with the death of the monks and higher order religious figures in the monastery. There would be celebratory masses conducted in the cloister. The remains of the deceased were often attended to in medieval times by the bone pickers. Significantly, neither lay people nor secular people of nobility were entombed within the monastery. It was restricted solely for the priestly residents. If this is compared to the Mississippian ceremonial centers of 
the twelfth to fifteenth centuries, there are marked similarities. Ceremonial centers only entombed the ranking priestly elites (and possible lay sacrifices). While perhaps not all of these religious figures were resident at that center, they were functioning within the religious area of influence of that center. What is less apparent is why some priestly elites were buried at secondary mound centers and others at the principal center. For example, there are secondary centers to Spiro such as Brackett, Horton, and Norman. What rules dictated which individuals were entombed at these locations rather than being transported to Spiro? While it may simply be a function of their prominence within the realm of Spiroan priestly elites, there could be other explanations embedded within the manner in which the ceremonial system operated (e.g., time of death, priestly order, etc.). One of the more striking features of Spiro as well as other Mississippian ceremonial centers is the large quantity of funerary objects placed with the deceased. Many of these items are thought to be associated with an individual's position or office, others are viewed as apparel restricted to the ranking elites/nobles within the society, and some are viewed as goods symbolically placed with individual at their death. All of these may be correct interpretations. However, it is unclear whether the priestly elites "owned" these items or if they were sacred items that were passed from individual to individual, perhaps along lineage lines, or through the particular religious rank that was held in society. If this was the case, then the items would function much as relics. Items brought from Cahokia to Spiro would certainly fall under this category. They were presumably intended for use by certain individuals or the rank of priestly elites. Ultimately, they were entombed along with the religious leaders at Spiro. Thus, many of the goods take on the role of "relics" rather than personal effects.

Religious relics also held prominence at European monasteries. Relics were generally brought to the monasteries by monks or abbots who acquired them on their journeys (pilgrimages). Some of these came from Rome as items blessed by the pope, others of greater antiquity, were venerated objects. The relics were attended to, ceremonies were held surrounding their presence, and they too, sometimes were buried with prominent leaders of the monastery, especially those who acquired sainthood. There was also considerable competition among monasteries for relics (Milis 1992:83), although this apparently never escalated to physical conflict. Considering the apparently greater emphasis placed on relics in the Mississippian ceremonial centers, would competition for such prestige items have escalated into conflict between neighboring ceremonial centers? There is evidence for conflict documented on engraved shell found at Spiro. Is this detailing typical socio-economic warfare, or is this conflict restricted to a religious level? It would be logical to assume that conflict depicted on items that can be identified as relics and that were ultimately entombed with religious leaders might be depicting scenes of religious conflict. Such depictions have a long history in religious iconography on a global scale.

The issue of violence or conflict also bears examination. There are a number of scenes of conflict depicted on the engraved shell at Spiro as well as examples from other centers. It has been argued that these depict the actions of "warrior" classes within Mississippian society (Phillips and Brown 1984). The presence of such groups was documented by early explorers (cf. Swanton 1942). However, it is possible that the early Spanish and French accounts overlooked some subtle aspects of these conflicts. For example, could these warriors be priestly warriors? Was the conflict one of a secular or sacred nature? We do not typically think of the monastic life in medieval Europe as containing militaristic elements. They are present, however. The Knights Templar and the Knights Hospitallers were essentially warrior societies of monks that evolved to protect pilgrims, especially those traveling to Jerusalem, from attacks by Muslims. The Knights Templar is the better known of these societies and has a long history as a rigidly stratified militaristic society (Lawrence 2001).

Another intriguing aspect of monastic life was the travels of the monks and abbots. While much of their life was a highly structured sequence of liturgical duties, they also traveled widely, to other monasteries as well as to Rome and other sacred places. Groups of lay people also traveled widely, making pilgrimages to monasteries where relics were held or to special "holy places." The number of pilgrims was never a significant 
percentage of the population, but they were sufficient to spread new religious practices as well as relics around central Europe and even to England. For example, the spread of Cluniacs as an order was the consequence of Saint Robert, one of their founders, traveling widely through Europe and to Rome. Items such as the flint clay pipes that originated at Cahokia and were transported to Spiro and Gahagan and other centers hint of potential pilgrimage-like functions within Mississippian society. Considering the high prestige of these figures/pipes, they undoubtedly were not moved from Cahokia to other centers by "lay" individuals. Whether they were transported by Spiroans visiting Cahokia or by Cahokian traveling to Spiro (for example), it would entail priestly elites making this journey. Such a journey takes on the appearance of a pilgrimage. Many other nonlocal prestige items (or relics) found at Spiro and other ceremonial centers may have found their way to these locations in a similar fashion. It did not require an elaborate or sophisticated redistributive trade network, only a limited number of priestly elites on a journey to a religious center. Such a system of pilgrimages to explain the movement of non-local prestige goods does not exist only during the relatively late Mississippian times; Sassaman (2005) has advocated such pilgrimages for the occurrence of many of the exotic goods present at Poverty Point some 4500 years ago.

\section{Architectural Elements}

In the previous section, the social aspects of monastic life have been compared to that of Spiro and other ceremonial centers to establish a metaphorical model. There are also a number of architectural parallels that can be drawn between the two religious systems.

There are obvious similarities in the landscape placement of monasteries with those of Mississippian ceremonial centers. Medieval Europe during the eleventh to fifteenth centuries remained quite isolated in many areas and transportation routes were limited. Monasteries, in need of arteries of movement, were typically placed adjacent to large streams or rivers. This provided for travel by boat as well as for pedestrian and horse paths along the waterways. Examination of Mississippian ceremonial center locations reveals essentially an identical pattern. They are typically along major streams and rivers. While traffic here was limited to boat (canoe) and pedestrian travel, it probably functioned much like that between medieval monasteries.

Monasteries were typically placed away from major urban areas. However, there were usually smaller towns nearby to provide the logistical support needed by the residents of the monasteries. In other cases, towns would evolve in the area surrounding the monastery as an economic response to the needs of the monastery. Similar patterns may have evolved at Mississippian ceremonial centers. It is difficult to determine whether centers were intentionally placed away from larger residential populations or that this pattern simply evolved in this fashion. However, it is clear, with the exception of Cahokia and some other centers, that many centers featured an isolated center of priestly elites with surrounding village communities.

There are also a number of parallels in the structure of monasteries and ceremonial centers. Mississippian ceremonial centers typically present a series of temple and burial mounds organized around a plaza or open space. While variation exists in this layout, a central theme remains present. The same can be said for the layout of monasteries. To some extent, they vary in design, but there remains a basic structure. The typical monastery of the Middle Ages consisted of a large church, a cloister nestled against it, a dormitory for the monks, chapter house, kitchen, refectory, offices, and storehouses in the central group (Brooke 2003). On the periphery would be found guest house(s), the abbot's lodgings, the infirmary, and a secondary cloister. There was a basic directional orientation to many of these facilities. For example, the cloister was located to the south of the church, the chapter house and the dormitories on the east walk, and the kitchen, refectory, and offices 
to the west. However, this architecture was frequently modified to conform to local preferences or landscape characteristics. The cloister though, was always central to the monastery layout.

The cloister of the monastery also appears to have functioned much in the same fashion as the plaza of the ceremonial center. It should be noted here that plaza is probably a misnomer in respect to Mississippian ceremonial centers. Plaza connotes a public space where the activities around the mounds were obviously of a sacred nature. It would perhaps be more appropriate to speak of a ceremonial field. Archeological investigations in these areas reveal a number of activities taking place in these open areas. The cloister within the monastery functioned in a like manner. The cloister was used for processionals as well as for ceremonies, and served as the symbolic referent for the clerics (Brooke 2003). Thus, ceremonial fields at centers may have a central function in the ritual use of space for most activities.

The remaining comparison is that of long term redefinition of the ritual space. Most Mississippian centers show indications of significant remodeling and/or expansion during their use life. This occurs at Spiro where Craig Mound and Brown Mound were both extensively remodeled (Brown 1996). This is especially true of Craig Mound which underwent numerous modifications until they were terminated with the building of the Great Mortuary between A.D. 1400-1450. Monasteries were also constantly in a state of change. Many of the monasteries were under construction or renovation for centuries. Much of this can be attributed to expansion but there are also cases of architectural change brought about by new religious practices or by what was viewed as architecturally acceptable. It is unclear whether symbolic referents were equally responsible for changes in Mississippian centers.

Thus far, social and architectural parallels have been established through comparison to monastic life in medieval Europe. Another critical aspect of such a religious system is the nature of the linkage that held it together. It has been demonstrated that monastic life functioned across Europe with a high degree of uniformity among the different orders. How was this uniformity maintained and are there parallels within the Mississippian World? The day to day life of monks was highly structured through practice of the liturgy; these rituals were highly ingrained into Catholicism. Considering that monasteries existed in many countries across Europe speaking diverse languages (e.g., French, Spanish, Italian, German, English, etc.), a logistical problem was maintenance of these frames of reference while also providing a mechanism for change when needed. This was accomplished through the use of Latin within the religious practice (when monks were permitted to speak). Thus, a common linguistic base was provided - perhaps specifically for such a purpose - to integrate the monastic communities and restrict nationalistic (secular) influence. If the use of the monastic life is a reasonable metaphor for the religious practices at ceremonial centers spread across the Southeast, then there would have been need of a similar overarching linking mechanism - and one may have existed.

Emanuel Drechsel has extensively studied the Mobilian jargon and believes it may have functioned as the lingua franca in the late prehistoric Southeastern United States. In considering the origins for Mobilian, he suggests that it existed in Mississippian society for inter-lingual communication among the diverse language communities that comprised the Mississippian World (Drechsel 1997:286-294) It is intriguing that Drechsels' (1997:286-288) mapping of the spatial extent of historical Mobilean jargon corresponds nicely with the archeologically defined boundaries of Mississippian societies. Mobilian would have functioned as the common liturgical base that served as the common thread for the Mississippian religious system. The use of a lingua franca that extends through the Mississippian World perhaps also provides a basis for the Southeastern Ceremonial Complex as well. If there is a religious system that extends throughout the Southeast, then its expression in the material world can be conveyed though a language that is spoken by the priestly elites among the various cultures that comprise "Mississippian." When the Frenchman Antoine Le Page Du Pratz visited the Natchez in the mid-eighteenth 
century, he questioned the Superior of the temple guardians about their beliefs and God. This conversation was conducted in the pidgeon or Mobilian jargon (Dreschel 1997:221). While commonly labeled as a "trade language," it is clear that the Mobilian language also served to convey the information of their religious world. Mobilian language was on the decline by the time of European contact and this may also parallel the overall decline in the Mississippian World by the mid-fifteenth century.

\section{A MODEL FOR MISSISSIPPIAN PRIESTLY ELITES}

These metaphorical examples demonstrate that there are alternate pathways to the archeological contexts of prestige goods observed at ceremonial centers in Mississippian societies, including Spiro and others found on the periphery of the Mississippian World. Can an alternative explanation to that of the redistributive economic system be presented from what has been learned from examining medieval monastic life in Europe? With the metaphorical comparisons and parallels presented here, there are numerous explanations that can be posed in terms of religious practices at Spiro as well as at some other Mississippian ceremonial centers

Visualize a Mississippian society where the religious system overarches but does not subsume the basic economic necessities. Priestly elites dominate society from ceremonial centers where they function as the principal residents with support from non-elites functioning as their attendants. Nearby villages support the ceremonial centers through supply of food and other needed material goods. The villages also frequently have resident priestly elites who maintain the link between sacred and secular worlds. This system appears much like that previously identified for Mississippian centers. However, there are some significant differences when prestige goods (relics) are added to the system.

Priestly elites travel often between centers, both within the region and outside of their ethnic territory. The purpose of such travel is to visit other centers where priestly elites reside. These pilgrimages result in visits to the sacred areas of the ceremonial centers, including facilities where religious leaders and their funerary offerings await further treatment and to repositories where religious leaders are buried with these offerings. Such visits for relics were frequent among the ceremonial centers and led to some relics being transported to other select centers. Here, Spiro must have had a particularly prominent role. The use of these goods and how they were portrayed in the religious system was partially a function of the specialized language utilized within the ceremonial context. Priestly elites could be highly protective of their relics and deceased religious leaders and had military societies to protect these interests. At specific times within the life of the relics, they were scheduled (destined?) to be buried with their priestly elite users at specific centers in the Mississippian World. Sites such as Nagle can be explained in the context of religious pilgrimages or perhaps even as a group of missionaries who would not be last to fall victim in their efforts to "spread the gospel." A similar explanation can also be proposed for the Sanders site. The Sanders site very well might have been an outpost, but not an economic one. If they are indeed representatives of Mississippian society as present at Spiro, perhaps they were the more successful missionaries who successfully inhabited the area alongside their Caddo neighbors.

Sometimes, this religious system lost credibility and a less structured polity controlled society. By the latter part of the fifteenth century, increasingly deleterious climatic conditions brought about the demise of the overarching religious order, with only vestiges of the religious order remaining. This is evidenced by warfare between neighboring Mississippian chiefdoms where there is desecration of other societies' temples and destruction of sacred objects (Dye 1994:45). Thus, the religious system encountered by Europeans in their early contacts with 
Southeastern tribes was undoubtedly diminished in respect to the religious/ceremonial system that flourished in late prehistoric times.

Here, there is a religious system that provides for the movement of prestige items (relics) for specific purposes within the religious order. The movement of prestige items has little to do with economic purpose and also has little bearing on the secular nature of settlements as redistributive centers. The religious order also functions to reinforce certain sacred practices within the society by maintaining them in separate sacred places administered by the priestly elite. More significantly, a special language exists to reinforce the dogma associated with religious practice through symbolic artistic design on the prestige items. Thus, the religious order through control of the access to prestige items (relics) and the use of a language specific to their "religious properties" controls how people interact with the religious/sacred aspects of life. Such religious practice can be found in many agricultural societies throughout the world with many existing until contact with Europeans and their capitalist economic order in the sixteenth century and later.

Such a model holds promise for explaining the structure and functionality of ceremonial centers on the western periphery of the Mississippian world such as Spiro, Harlan, and Norman in the Arkansas River valley of Oklahoma. The potential practices embodied within a religious context as explained through use of a monastic metaphor supports the accumulation of "relics" at ceremonial centers without the need for explaining their presence in an economic/trade-based system. As alluded to in the introduction, this is not to argue that trading/redistributive practices did not take place in these western Mississippian (Caddoan) cultures, but that it was perhaps less religious in nature and that the sacred aspect of religious life functioned apart from this. This explanation would account for the failure to find backflow goods to the redistributive center, because the ceremonial centers did not have such a function. They were resident only for their religious purpose and for the practitioners of their rituals and ceremonies.

With all that said, it is not the intent of this article to replace one western world metaphorical model with another. The above scenario will hopefully serve as a base from which to more critically examine notions of economic and religious practices in the Arkansas River Caddoan and perhaps elsewhere in the Mississippian World. Such a suggestion is neither novel nor unique. Pauketat (2005:204-205) has pursued the allegorical legends of Red Horn among Siouan-speaking groups in the upper Midwest, tracing the relationship of a mythological figure with long red-painted braids and human head earrings to a legendary history in the Cahokian heartland. It is perhaps no coincidence that the Resting Warrior flint clay pipe that was ultimately deposited at Spiro bears striking resemblances to this legendary figure. With sacred histories of this nature bonded to concepts such as pilgrimages, relics, and priestly functions at monasteries, alternative explanation will hopefully serve to generate comparative testing of the two metaphorical models and their value in understanding the nature of ceremonial centers in the Arkansas River valley Caddoan region as well as elsewhere in the Mississippian World.

\section{REFERENCES CITED}

Barker, Alex W., Craig E. Skinner, M. Steven Shackley, Michael D. Glascock, and J. Daniel Rogers

2002 Mesoamerican Origin for an Obsidian Scraper from the Precolumbian Southeastern United States. American Antiquity 67:103-108.

Bell, Robert E.

1947 Trade Materials at Spiro as Indicated by Artifacts. American Antiquity 12: 181-184. 
1972 The Harlan Site, Ck-6, A Prehistoric Mound Center in Cherokee County, Eastern Oklahoma. Oklahoma Anthropological Society Memoir 2, Norman.

Brooke, Christopher

2003 The Age of Cloister: The Story of Monastic Life in the Middle Ages. Hiddenspring Publishers. London.

Brooks, Robert L.

1996 The Arkansas Valley: A New Paradigm, Revisionist Perspectives, and the Archaeological Record. Caddoan Archaeology Newsletter 7:17-27.

Brown, James

1966a Spiro Studies, volume 1. Description of the Mound Group. First Part of the Second Annual Report of Caddoan Archaeology - Spiro Focus Research. University of Oklahoma Research Institute. Norman

1966b Spiro Studies, volume 2. The Graves and Their Content. Second Part of the Second Annual Report of Caddoan Archaeology - Spiro Focus Research. University of Oklahoma Research Institute. Norman.

1971 Spiro Studies, volume 3. Pottery Vessels. First Part of the Third Annual Report of Caddoan Archaeology - Spiro Focus Research. University of Oklahoma Research Institute. Norman.

1975 Spiro Art and its Mortuary Context. In Death and the Afterlife in Pre-Columbian America, edited by Elizabeth P. Benson, pp. 1-32. Dumbarton Oaks Research Library and Collections, Washington D. C

1983 Spiro Exchange Connections Revealed by Sources of Imported Raw Materials. In Southeastern Natives and Their Pasts, edited by Don G. Wyckoff and Jack L. Hofman, pp. 129-153.. Oklahoma Archeological Survey, Studies in Oklahoma's Past 11, Norman.

1989 On Style Divisions of the Southeastern Ceremonial Complex: A Revisionist Perspective. In Southern Ceremonial Complex, Artifacts, and Analysis: the Cottonlandia Conference, edited by Patricia Galloway, pp. 183-204. University of Nebraska Press. Lincoln.

1996 The Spiro Ceremonial Center, 2 vols. Museum of Anthropology Memoir 29, University of Michigan. Ann Arbor.

Brown, James A. and J. Daniel Rogers

1989 Linking Spiro's Artistic Styles: the Cooper Connection. Southeastern Archaeology 8:1-8.

Brues, Alice

1957 Skeletal Material from the Nagle Site. Bulletin of the Oklahoma Anthropological Society 5:93-99.

Bruseth, James E., Diane E. Wilson, and Timothy K. Perttula

1995 The Sanders Site: A Spiroan Entrepôt in Texas? Plains Anthropologist 40:223-236.

Carney, Gary

1993 The Evidence and Character of Exchange Between Arkansas Basin Caddoan and Plains Villagers: A.D. 900-1450. Masters thesis, College of Liberal Studies. University of Oklahoma, Norman.

Derrick, Sharon M. and Diane Wilson

1997 Cranial Modeling as an Ethnic Marker among the Prehistoric Caddo. Bulletin of the Texas Archeological Society 68: 139-146.

Drass, Richard and Dennis Peterson

1981 An Engraved Shell Gorget from Grady County, Oklahoma. Bulletin of the Oklahoma Anthropological Society 30: 67-79.

Dreschel, Emanuel J.

1997 Mobilian Jargon: Linguistic and Sociohistorical Aspects of a Native American Pidgin. Clarendon Press. Oxford.

Duffield, Lathel F.

1964 Engraved Shell from the Craig Mound at Spiro, Le Flore County, Oklahoma. Oklahoma Anthropological Society Memoir 1. 
Dye, David H.

1994 The Art of War in the Sixteenth-Century Central Mississippi Valley. In Perspectives on the Southeast: Linguitics, Archaeology, and Ethnohistory, edited by Patricia B. Kwachka, pp. 44-60. The University of Georgia Press. Athens.

Earle, Timothy

1998 How Chiefs Come to Power: The Political Economy in Prehistory. Stanford University Press. Stanford.

Emerson, Thomas

2004 Greater Cahokia and the Caddo Connection. Paper presented at the 46th Caddo Conference. Natchitoches.

Emerson, Thomas E. and Jeffrey S. Girard

2004 Dating Gahagan and Its Implications for Understanding Cahokia-Caddo Interactions. Southeastern Archaeology 23: 57-64.

Emerson, Thomas E. and Randall Hughes

2000 Figurines, Flint Clay Sourcing, the Ozark Highlands, and Cahokia Acquisition. American Antiquity 65:79-101.

Ferring, C. Reid and Timothy K. Perttula

1987 Defining the Provenance of Red Slipped Pottery from Texas and Oklahoma by Petrographic Methods. Journal of Archaeological Science 14:437-456.

Finkelstein, J. Joe

1940 The Norman Site Excavations Near Wagoner, Oklahoma. The Oklahoma Prehistorian 3:2-15.

Hamilton, Henry W.

1952 The Spiro Mound. Missouri Archaeologist 14: 17-106

Hirth, Kenneth G.

1978 Interregional Trade and the Formation of Prehistoric Gateway Communities. American Antiquity 43:35-45.

Jackson, A. T., Marcus S. Goldstein, and Alex D. Krieger

2000 The 1931 Excavations at the Sanders Site, Lamar County, Texas. Archival Series 2. Texas Archaeological Research Laboratory. University of Texas, Austin.

Kozuch, Laura

2002 Olivella Beads from Spiro and the Plains. American Antiquity 67:697-709.

Krieger, Alex D.

1946 Culture Complexes and Chronology in Northern Texas With Extension of Puebloan Datings to the Mississippian Valley. Bulletin 4640. University of Texas. Austin.

Lawrence, C. H.

2001 Medieval Monasticism: Forms of Religious Life in Western Europe in the Middle Ages. Longman Press. Harlow, England.

Milis, Ludo J. R.

1992 Angelic Monks and Earthly Men: Monasticism and its Meaning to Medieval Society. The Boydell Press. Woodbridge, Suffolk, England.

Orr, Kenneth G.

1952 Survey of Caddoan Area Archaeology. In Archaeology of Eastern North America, edited by James B. Griffin, pp. 239-255. University of Chicago Press. Chicago.

Owsley, Douglas W.

1989 The History of Bioarchaeological Research in the Southern Great Plains. In From Clovis to Comancheros: Archeological Overview of the Southern Great Plains, edited by Jack L. Hofman, Robert L. Brooks, Joe S. Hays, Douglas W. Owsley, Richard L. Jantz, Murray K. Marks, and Mary Manheim. Research Series No. 35. Arkansas Archeological Survey, Fayetteville. 
Owsley, Douglas W. and Richard L. Jantz

1999 Databases for Paleoamerican Skeletal Biology Research. In Who Were the First Americans?, edited by R. Bonnichsen, pp, 79-96. Center for the Study of the First Americans. Oregon State University, Corvallis.

Pauketat, Timothy R.

2000 Cahokian Political Economy. In Cahokia: Domination and Ideology in the Mississippian World, edited by Timothy R. Pauketat and Thomas E. Emerson, pp. 30-51. University of Nebraska Press. Lincoln.

2005 The Forgotten History of the Mississippian. In North American Archaeology, edited by Timothy R. Pauketat and Diana DiPaolo Loren, pp. 187-211. Blackwell Publishing Company. Oxford.

Peregrine, Peter

1992 Mississippian Evolution: A World Systems Pespective. Prehistory Press. New York.

Peebles, Christopher S. and Susan B. Kus

1977 Some Archaeological Correlates of Ranked Societies. American Antiquity 42:421-428.

Phillips, Philip and James A. Brown

1984 Pre-Columbian Shell Engraving s from the Craig Mound at Spiro, Oklahoma. Peabody Museum Press. Harvard University. Cambridge

Rogers, J. Daniel

1983 Social Ranking and Change in the Harlan and Spiro Phases of Eastern Oklahoma. In Southeastern Natives and Their Pasts, edited by Don G. Wyckoff and Jack L. Hofman, pp. 17-128. Oklahoma Archeological Survey, Studies in Oklahoma's Past 11.

1996 Markers of Social Integration: The Development of Centralized Authority in the Spiro Region. In Political Structure and Change in the Prehistoric Southeastern United States, edited by John F. Scarry, pp. 53-68. University of Florida Press. Gainesville.

Sahlins, Marshall

1972 Stone Age Economics. University of Chicago Press. Chicago.

Sassaman, Kenneth E.

2005 Structure and Practice in the Archaic Southeast. In North American Archaeology, edited by Timothy R. Pauketat and Diana DiPaolo Loren, pp. 79-107. Blackwell Publishing Company. Oxford.

Schambach, Frank F.

1993a Some New Interpretations of Spiroan Culture History. In Archaeology of Eastern North America: Papers in Honor of Stephen Williams, edited by James B. Stoltman, pp. 187-230. Mississippi Department of Archives and History, Archaeological Report No. 25, Jackson

1993b Spiroan Entrepôts and Beyond the Western Border of the Trans-Mississippi South. Caddoan Archaeology Newsletter 4(2):11-26.

1995 A Probable Spiroan Entrepôt in the Red River Valley in Northeast Texas. Caddoan Archaeology Newsletter 6(1):1025.

1996 The Womack, Gilbert, and Pearson Sites: Early Eighteenth Century Tunican Entrepôts in Northeast Texas? Caddoan Archaeology Newsletter 7(3): 9-31.

1999 A New Intepretation of the Role of the Tunica in the Culture History of the Southeast and the Southern Plains. In Arkansas Archaeology: Essays in Honor of Dan and Phyllis Morse, edited by Robert C. Mainfort and Marvin D. Jeter, pp. 169-224. University of Arkansas Press. Fayetteville.

2000 Spiroan Traders, the Sanders Site, and the Plains Interaction Sphere: A Reply to Bruseth, Wilson, and Perttula. Plains Anthropologist 45: 7-33.

Spielmann, Kathleen

1990 Interdependence in the Prehistoric Southwest: An Ecological Analysis of Plains-Puebloan Interaction. Garland Press. New York.

Swanton, John R.

1942 Source Material on the History and Ethnology of the Caddo Indians. Bureau of American Ethnology Bulletin 132. US Government Printing Office. Washington, DC. 
Wallerstein, Immanuel

1979 The Capitalist World-Economy. Cambridge University Press. Cambridge.

Webster's New Universal Unabridged Dictionary

1979 World Publishing Company. New York.

Welch, Paul D.

1991 Moundville's Economy. University of Alabama Press. Tuscaloosa.

Wyckoff, Don G.

2001 Native American Trade a Millennium Ago. Gilcrease Journal 19 (2): 49-63. 